University of Nebraska - Lincoln

DigitalCommons@University of Nebraska - Lincoln

Faculty Papers and Publications in Animal

Science

Animal Science Department

January 1968

\title{
WEIGHT GAIN AND CARCASS MEASUREMENTS OF PIGS FROM GILTS FED ADEQUATE VS. PROTEIN-FREE DIETS DURING GESTATION
}

W. G. Pond

Cornell University

J. A. Dunn

Cornell University

G. H. Wellington

Cornell University

J. R. Stouffer

Cornell University

L. Dale Van Vleck

University of Nebraska-Lincoln, dvan-vleck1@unl.edu

Follow this and additional works at: https://digitalcommons.unl.edu/animalscifacpub

Part of the Animal Sciences Commons

Pond, W. G.; Dunn, J. A.; Wellington, G. H.; Stouffer, J. R.; and Van Vleck, L. Dale, "WEIGHT GAIN AND CARCASS MEASUREMENTS OF PIGS FROM GILTS FED ADEQUATE VS. PROTEIN-FREE DIETS DURING GESTATION" (1968). Faculty Papers and Publications in Animal Science. 325.

https://digitalcommons.unl.edu/animalscifacpub/325

This Article is brought to you for free and open access by the Animal Science Department at DigitalCommons@University of Nebraska - Lincoln. It has been accepted for inclusion in Faculty Papers and Publications in Animal Science by an authorized administrator of DigitalCommons@University of Nebraska - Lincoln. 
Pond, W. G., J. A. Dunn, G. H. Wellington, J. R. Stouffer, and L. D. Van Vleck. D. 1968. Weight gain and carcass measurements of pigs from gilts fed adequate vs. protein-free diets during gestation. Journal of Animal Science 27:1503-1506.

Abstract: Fifty-two weanling pigs from six litters(Pond et al., 1968) were fed a standard $18 \%$ protein corn-soybean meal diet from weaning to slaughter. The six litters were from gilts paired on the basis of parturition date so that one gilt fed the control diet and one fed the "protein-free" diet $(0.5 \%$ protein) from week 4 of pregnancy to parturition made tip each pair. Each dam was fed the control diet throughout lactation and nursed one-half of her own litter and one-half of a pairmate's litter resulting from reciprocal transfer of one-half of each litter at birth. Individual bodyweight gains and feed consumption of each litter recorded from weaning to slaughter at $93 \mathrm{~kg}$. revealed no differences associated with prenatal or preweaning treatment. Carcass backfat and cross-sectional area of the I. dorsi muscle between the 10th and llth ribs also failed to reveal differences in carcass characteristics which could be considered as a crude index of muscle cell number as influenced by prenatal and early postnatal protein nutrition. It is concluded that in pigs the dam acts as an efficient "buffer" to at least partially protect the developing fetus against the effects of maternal protein deprivation during the final three-fourths of one gestation period.

Copyright ${ }^{\odot} 1968$ American Society of Animal Science. Used by permission. 


\title{
WEIGHT GAIN AND CARCASS MEASUREMENTS OF PIGS FROM GILTS FED ADEQUATE VS. PROTEIN-FREE DIETS DURING GESTATION ${ }^{1}$
}

\author{
W. G. Pond, J. A. Dunn, G. H. Wellington, J. R. Stouffer and L. D. Van Vleck \\ Cornell University, Ithaca, New York"
}

$\mathrm{T}$ HE effect of protein levels of swine gestation diets on postnatal growth and development of the progeny has received only limited attention. Clawson et al. (1963) and Rippel et al. (1965) reported normal reproduction in gilts fed $5 \%$ protein diets. Normal reproduction has also been reported in gilts fed diets almost devoid of protein from day 24 of pregnancy to parturition (Pond et al., 1968). The present data describe the postweaning weight gain and carcass characteristics of pigs from those gilts.

\section{Materials and Methods}

The animals used in this experiment were continued from a previous experiment (Pond et al., 1968). Briefly, the previous experiment involved a comparison of the reproductive performance (number of pigs per litter, individual pig birthweight and livability) and lactation performance (preweaning weight gains and weaning weight of pigs) of three gilts fed a protein-free diet from week 4 of pregnancy to parturition and three fed an adequate diet throughout gestation. Reciprocal transfer of one-half of each litter at 2 days of age to a foster dam produced weight gains in favor of pigs suckling control gilts, indicating a greater effect of postnatal than of prenatal treatment on weaning weight.

The present report describes the postweaning performance of 52 pigs from six litters representing the four previous treatment groups: (1) pigs from "protein-free" dams (fed a protein-free diet during gestation) and kept with their own dam through the suckling period (PF-PF), (2) pigs from "protein-free" dams but transferred to foster "control" dams (fed an adequate diet during gestation) through the suckling period $(\mathrm{PF}-\mathrm{C}),(3)$ pigs from "control" dams but transferred to foster "protein-free". dams through the suckling period (C-PF) and (4) pigs from "control"

1 Grateful acknowledgments are due Robert White, James $O$ 'Connor and George Kiger for their assistance in this work.

2 Department of Animal Science. dams and kept with their own dam through the suckling period $(\mathrm{C}-\mathrm{C})$. The six litters were from gilts paired on the basis of parturition date so that one $\mathrm{C}$ and one $\mathrm{PF}$ gilt made each pair. Dams were fed $1.82 \mathrm{~kg}$. of feed daily throughout gestation and ad libitum on the complete diet throughout lactation. All pigs were castrated at 3 to $4 \mathrm{wk}$. and weaned at $6 \mathrm{wk}$. of age. At this time, full-sibs were penned together in $3 \times 3.5 \mathrm{~m}$. concrete-floor pens and fed a standard $18 \%$ protein cornsoybean meal diet from a wooden self-feeder to slaughter weight of approximately $93 \mathrm{~kg}$. Feed consumption of each litter was recorded. Water was supplied twice daily from cast iron troughs.

A blood sample was taken from the anterior vena cava of each pig micway through the postweaning period ( 90 to 110 cays of age) for serum protein determination (Gornall et al., 1949).

Carcass measurements were taken on the chilled carcass after $24 \mathrm{hr}$. at $4^{\circ} \mathrm{C}$. These were backfat (average of three measurements taken on the split carcass at the first rib, last rib and last lumbar vertebra), length (anterior edge of first rib to pubic bone) and cross-sectional area of the longissimus dorsi muscle (as determined by planimeter from a tracing of the cut surface between the 10th and 11th rib).

The data were treated statistically by analysis of variance of unweighted means as illustrated in table 2. The means square for prenatal $\times$ pair interaction was used to test the prenatal effect and the residual mean square was used to test postnatal and prenatal $\times$ postnatal effects.

\section{Results and Discussion}

The results are summarized in table 1 and the mean squares from analyses of variance are in table 2 . There were no significant differences related to prenatal or preweaning treatment for any of the criteria considered except for a difference in initial (weaning) 
TABLE 1. EFFECT OF GESTATION DIET OF GILTS ON SUBSEQUENT GROWTH AND CARCASS MEASUREMENTS OF THE OFFSPRING

\begin{tabular}{|c|c|c|c|c|c|c|}
\hline \multirow[t]{2}{*}{ Gestation diet of dam } & \multicolumn{3}{|c|}{ Control } & \multicolumn{3}{|c|}{ Protein-free } \\
\hline & Control & $\begin{array}{l}\text { Protein- } \\
\text { free }\end{array}$ & Combined & Control & $\begin{array}{l}\text { Protein- } \\
\text { free }\end{array}$ & Combined \\
\hline No, of pigs & 15 & 13 & 28 & 12 & 12 & 24 \\
\hline Weaning wt., $\mathrm{kg}$. & 9.7 & 8.2 & 9.0 & 10.0 & 8.0 & 9.0 \\
\hline Daily gain, postwean, gm. & 677 & 716 & 697 & 716 & 728 & 722 \\
\hline Age at slaughter, da. & 167 & 161 & 164 & 159 & 158 & 159 \\
\hline Slaughter wt, kg. & 93.0 & 92.7 & 92.9 & 93.0 & 91.0 & 92.5 \\
\hline Da. gain, birth to slaughter, gm. & 557 & 571 & 564 & 583 & 578 & 581 \\
\hline Backfat, cm. & 3.28 & 3.26 & 3.27 & 3.03 & 3.26 & 3.15 \\
\hline Area of $l$. dorsi, $\mathrm{cm}^{2}$ & 28.3 & 26.8 & 27.6 & 26.8 & 26.0 & 26.4 \\
\hline Length, $\mathrm{cm} .^{a}$ & 75.7 & 74.9 & 75.3 & 75.6 & 74.0 & 74.8 \\
\hline Serum protein, $\mathrm{gm} . / 100 \mathrm{ml}{ }^{3}$ & 6.6 & 6.4 & 6.5 & 7.0 & 7.1 & 7.1 \\
\hline Gain/unit feed, kg. & $\ldots$ & $\ldots$ & 0.354 & $\ldots$ & $\ldots$ & 0.359 \\
\hline
\end{tabular}

a $\mathrm{C}-\mathrm{C}$ and $\mathrm{PF}-\mathrm{C}$ greater than $\mathrm{PF}-\mathrm{PF}$ and $\mathrm{C}-\mathrm{PH} \quad(\mathrm{P}<.01)$

b $\mathrm{PF}-\mathrm{PF}$ and $\mathrm{PF}-\mathrm{C}$ greater than $\mathrm{C}-\mathrm{PF}$ and $\mathrm{C}-\mathrm{C}(\mathrm{P}<.01)$. Also, prenatal $\times$ postnatal interaction $(\mathrm{P}<.01)$

weight in favor of pigs suckling control gilts regardless of prenatal treatment. Also, serum protein of pigs born to $\mathrm{PF}$ dams was significantly higher $(\mathrm{P}<.01)$ than that of pigs born to $C$ dams and carcasses of pigs that had suckled $\mathrm{C}$ gilts were slightly longer $(\mathrm{P}<.01)$ than those of pigs that had suckled PF gilts. The biological significance of these differences is not clear. In the case of serum protein, it would appear that this might be a compensatory response since serum protein of these pigs was lower than that of pigs from $C$ gilts at birth (Pond et al., 1968). One might have ex- pected a detrimental effect on subsequent performance of pigs from PF gilts based on earlier work in which low protein gestation diets were used (Evvard et al., 1914; Jespersen and Olsen, 1940) and on the relationship between cell number established during early life and subsequent growth (Hammond, 1962). However, Rippel (1967) concluded, from an exhaustive review of the subject that "the usual criteria of reproductive performance (total and live pigs farrowed, birthweight and livability) are unresponsive to various levels of protein during the last third of gestation." Widdowson

TABLE 2. MEAN SQUARES OF ANALYSIS OF VARIANCE OF SEVERAL CRITERIA

\begin{tabular}{|c|c|c|c|c|c|c|}
\hline \multirow[b]{2}{*}{ Source of variation } & \multirow[b]{2}{*}{ d.f. } & \multicolumn{5}{|c|}{ M.S. } \\
\hline & & $\begin{array}{l}\text { Wean. } \\
\text { wt. }\end{array}$ & $\begin{array}{l}\text { Postwean. } \\
\text { gain }\end{array}$ & $\begin{array}{c}\text { Postwean. } \\
\text { ADG }\end{array}$ & $\begin{array}{l}\text { Age at } \\
\text { slaughter }\end{array}$ & $\begin{array}{l}\text { ADG, birth } \\
\text { to slaughter }\end{array}$ \\
\hline Prenatal & 1 & 0.46 & 1.98 & 8707 & 364.71 & 3194 \\
\hline Pair & 2 & 2.36 & 4.28 & 5071 & 214.87 & 1880 \\
\hline Prenatal $\times$ pair & 2 & 5.06 & 20.52 & 15921 & 708.02 & 6440 \\
\hline Postnatal & 1 & $38.71^{*}$ & 14.01 & 7376 & 102.81 & 297 \\
\hline Prenatal $\times$ postnatal & 1 & 0.94 & 0.19 & 1985 & 65.78 & 1049 \\
\hline \\
\hline $\begin{array}{l}\text { Prenatal } X \text { pair } X\} \\
\text { postnatal }\end{array}$ & 4 & 11.82 & 17.69 & 2831 & 195.91 & 1584 \\
\hline \multirow[t]{2}{*}{ Residual } & 40 & 2.00 & 7.45 & 3504 & 158.31 & 1633 \\
\hline & d.f. & Slaughter wt. & Backfat & $\begin{array}{l}\text { Loin eye } \\
\text { area }\end{array}$ & Length & $\begin{array}{l}\text { Serum } \\
\text { protein }^{a}\end{array}$ \\
\hline Prenatal & 1 & 1.99 & 0.19 & 16.0 & 3.4 & $3.05 * *$ \\
\hline Pair & 2 & 5.18 & 0.23 & 11.1 & 12.8 & 0.69 \\
\hline Prenatal $\times$ pair & 2 & 6.01 & 0.30 & 28.1 & 8.2 & 0.04 \\
\hline Postnatal & 1 & 6.05 & 0.14 & 16.6 & $17.5^{*}$ & 0.02 \\
\hline Prenatal $\times$ postnatal & 1 & 2.04 & 0.19 & 1.1 & 1.6 & 0.34 \\
\hline \multicolumn{7}{|l|}{ Pair $\times$ postnatal } \\
\hline$\underset{\text { postnatal }}{\text { Prenatal }} \times$ pair $X\}$ & 4 & 3.88 & 0.10 & 1.4 & 4.1 & 0.11 \\
\hline Residual & 40 & 6.11 & 0.10 & 12.1 & 2.4 & 0.16 \\
\hline
\end{tabular}

a One blood sample was lost, therefore, residual d.f. is 39 for serum protein.

* $\mathrm{P}<.01$. 
and McCance (1960) obtained differences which persisted to adulthood in body size of rats fed a low or high plane of nutrition up to weaning. The implication was that a restricted plane of nutrition at this stage of development limited permanently the cell number. Winick and Noble (1966) have suggested that cell number is established during late prenatal life in the rat, whereas Joubert (1956) has suggested that the increase in muscle cell number in the sheep ceases after the third month of fetal life. The corresponding time in the pig is not known, but it is probable that the pig more nearly resembles the rat than the sheep (Hammond, 1962).

Since there was only a small and statistically nonsignificant reduction in birthweight of pigs from PF gilts used in the present study, it would appear that the nutritional environment of the fetus was not greatly affected by deprivation of dietary protein to the dam from week 4 of pregnancy to parturition. If this was the case, the effect on cell number was minimal and perhaps nil. This would account for the lack of prenatal treatment on subsequent weight gain and carcass measurements observed.

There is a considerable body of data in the literature showing an effect of level of energy intake during early life on subsequent performance of pigs (McMeekan, 1940a,b,c; Lucas et al., 1962; Robinson, 1964; Nielsen, 1964). However, Meade (1967) found no effect of diet from 3 to 8 or $9 \mathrm{wk}$. of age on subsequent performance or carcass measurements. Elsley and McDonald (1964) concluded from their own data and from recalculations of the data of McMeekan (1940a,b,c) that plane of nutrition has no effect on the carcasses of pigs when variations in fat content are excluded. In the present experiment the small, but statistically significant, greater initial (weaning) weight of $\mathrm{C}-\mathrm{C}$ and $\mathrm{PF}-\mathrm{C}$ pigs as compared to $\mathrm{C}-\mathrm{PF}$ and $\mathrm{PF}-\mathrm{PF}$ pigs apparently did not represent a sufficient difference to significantly affect subsequent performance. It is concluded that the gilt acts as an efficient "buffer" to at least partially protect the developing fetus against the effects of maternal protein deprivation extended over the final three-fourths of one gestation period.

\section{Summary}

Fifty-two weanling pigs from six litters (Pond et al., 1968) were fed a standard 18\% protein corn-soybean meal diet from weaning to slaughter. The six litters were from gilts paired on the basis of parturition date so that one gilt fed the control diet and one fed the "protein-free" diet $(0.5 \%$ protein) from week 4 of pregnancy to parturition made up each pair. Each dam was fed the control diet throughout lactation and nursed one-half of her own litter and one-half of a pairmate's litter resulting from reciprocal transfer of one-half of each litter at birth. Individual bodyweight gains and feed consumption of each litter recorded from weaning to slaughter at $93 \mathrm{~kg}$. revealed no differences associated with prenatal or preweaning treatment. Carcass backfat and cross-sectional area of the $l$. dorsi muscle between the 10th and 11 th ribs also failed to reveal differences in carcass characteristics which could be considered as a crude index of muscle cell number as influenced by prenatal and early postnatal protein nutrition. It is concluded that in pigs the dam acts as an efficient "buffer" to at least partially protect the developing fetus against the effects of maternal protein deprivation during the final three-fourths of one gestation period.

\section{Literature Cited}

Clawson, A. J., H. L. Richards, G. Matrone and E. R. Barrick. 1963. Influence of level of total nutrient and protein intake on reproductive performance in swine. J. Animal Sci. 22:662.

Elsley, F. W. H. and I. McDonald. 1964. The effect of plane of nutrition in the carcass of pigs and lambs when variations in fat content are excluded. An. Prod. 6:141.

Evvard, J. M., W. Arthur and S. C. Guernsey. 1914. The effect of calcium and protein fed to pregnant swine on the size, vigor, bone, cost and condition of the offspring. Am. J. Physiol. 34:312.

Gornall, A. G., C. J. Bardawell and M. M. David. 1949. Determination of serum proteins by means of the buiret reaction. J. Biol. Chem. 177:751.

Hammond, J. 1962. The physiology of growth. In J. T. Morgan and D. Lewis, [ed.], Nutrition of Pigs and Poultry. Butterworths, London.

Jespersen, J. and H. M. Olsen. 1940. Beretn. Forsøgslab. Copenhagen 192. In H. H. Cole and P. T. Cupps [ed.] Reproduction in Domestic Animals. Academic Press Inc., New York. 1959.

Joubert, D. M. 1956. An analysis of factors influencing post-natal growth and development of the muscle fiber. J. Agr. Sci. 47:59.

Lucas, I. A. M., R. M. Livingstone and I. McDonald. 1962. Further observations on the effects of growth checks in pigs of $50 \mathrm{lb}$. liveweight and over. An. Prod. 4:195.

McMeekan, C. P. 1940a. Growth and development in the pig, with special reference to carcass quality characters. I. J. Agr. Sci. 30:276.

McMeekan, C. P. 1940b. Growth and development in the pig, with special reference to carcass quality 
characters. II. The influence of the plane of nutrition on growth and development. J. Agr. Sci. 30:387.

McMeekan, C. P. 1940c. Growth and development in the pig, with special reference to carcass quality character. III. Effect of the plane of nutrition on the form and the composition of the bacon pig. J. Agr. Sci. 30:511.

Meade, R. J. 1967. Effects of the young pig's diet. Influence of dietary regimen and performance of pigs to eight or nine weeks of age on subsequent rate and efficiency of gain and on carcass characteristics. Feedstuffs 39:46.

Nielsen, H. E. 1964. Effects in bacon pigs of differing levels of nutrition to $20 \mathrm{~kg}$. body weight. An. Prod. 6:301.

Pond, W. G., W. C. Wagner, J. A. Dunn and E. F.
Walker, Jr. 1968. Reproduction and early postnatal growth of progeny in swine fed a proteinfree diet during gestation. J. Nutr. 94:309.

Rippel, R. H., O. G. Rasmussen, A. H. Jensen, H. W. Norton and D. E. Becker. 1965. Effect of level and source of protein on reproductive performance of swine. J. Animal Sci. 24:203.

Rippel, R. H. 1967. Protein and amino acid nutrition of gravid swine. J. Animal Sci. 26:526.

Robinson, D. W. 1964. The plane of nutrition and compensatory growth in pigs. An. Prod. 6:227.

Widdowson, E. M. and R. A. McCance. 1960. Some effects of accelerating growth. I. General somatic development. Proc. Royal Soc. 13:152:188.

Winnick, M. and A. Noble. 1966. Cellular response in rats during malnutrition at various ages. $\mathrm{J}$. Nutr. 89:300. 